\title{
Smoke signals snuffed out in San Francisco
}

San Francisco. A Congressional Committee has recommended the axing of funding for a research project which has revealed links between legislators and tobacco interests, and brought damaging internal tobacco industry documents to the attention of the public.

The three-year, $\$ 600,000$ grant for work being carried out by Stanton A. Glantz, professor of medicine at the University of California at San Francisco, was singled out in a report to the National Cancer Institute (NCI) by the House Appropriations Committee with responsibility for Congress' $\$ 12$ billion allocation to the agency.

Representative John Edward Porter (Republican, Illinois) has told NCI to stop the grant to Glantz. The research should not have been funded by NCI, or any of the National Institutes of Health, he said, on the grounds that it involved political and social science, not medical or clinical research.

Glantz has published nearly a dozen reports in peer-reviewed journals in the past

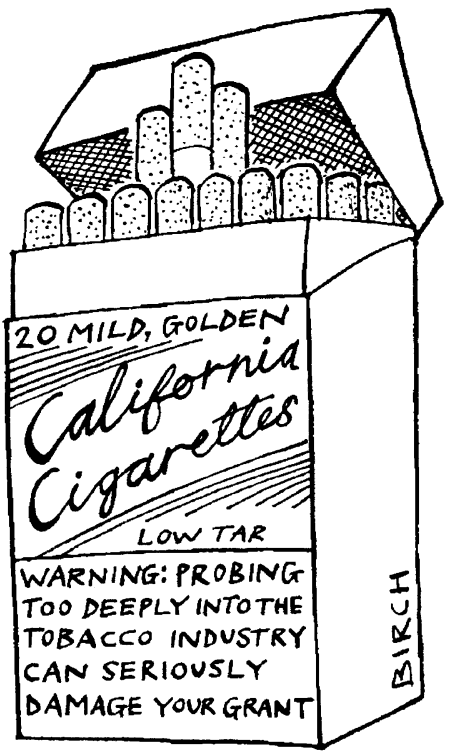

year alone, on the basis of work paid for by the NCI grant. The Journal of the American Medical Association recently devoted an entire issue to an analysis by Glantz's group of internal documents from Brown \& Williamson Tobacco Co., which asserted that the company knew of the cancer risks associated with tobacco much earlier than the scientific community, and tried to cover up its findings.

A study published last year also claimed that state legislators who receive money from the tobacco industry are 42 times more likely to vote in favour of the industry than those who do not. Glantz is now probing the political activities of the tobacco industry in six states.

Porter said that the committee was not passing judgement on the quality of Glantz's

grant proposal, but merely felt "strongly" that such research fell outside NCI's mandate. Dave Kohn, a spokesman for Porter, says Porter hoped the National Institutes of Health would ask the Department of Health and Human Services to continue funding for Glantz's work through its discretionary funds.

But Glantz says that the agency had solicited work on the public policy aspects of tobacco control, and that his grant was just one of several in this area. "Just as you need to understand a vector of a disease to control it , the tobacco industry is the vector for lung cancer and heart disease," Glantz says. If Porter is successful, he adds, "that's going to undermine public confidence in the scientific community and the whole process".

Dr Tom Novotny, an epidemiologist and adjunct professor at the UC-Berkeley School of Public Health, says Glantz's work is essential to understanding the root cause of lung cancer and other diseases caused by smoking. The decision is an insult to academic freedom, he says. "It's a bit frightening because it injects politics into the determination of the way scientific research is carried out."

\section{\$1 billion R\&D spender emerges}

Oxford, UK. Sweden's Pharmacia and Upjohn of the United States last week agreed to merge to create one of the world's ten largest pharmaceutical groups.

The merger continues a trend of consolidation among the world's pharmaceutical companies, prompted by the need to cut costs and improve efficiency because of pressure from increasingly budget-conscious governments.

It is also predicted that only the biggest companies will be able to afford the soaring costs of the research and development needed to produce blockbuster drugs that command high prices.

Had the new company, which is called Pharmacia \& Upjohn, existed last year, it would have had 1994 sales of nearly $\$ 7$ billion, 34,500 employees and an R\&D budget of more than $\$ 1$ billion. The company anticipates cutting its workforce by 4,000 , but declines to say where cuts would be made. Sales and marketing positions, where most duplication occurs, are likely to be the main target, but $R \& D$ jobs may not be immune.

Pharmacia \& Upjohn is likely to turn to its researchers as a source of new growth. "Uniting the respective $R \& D$ strengths of Pharmacia and Upjohn in molecular biology, chemistry and pharmacology and other key disciplines will create a powerful engine for innovation and new product
$\mathrm{NCI}$, which is not legally required to obey the directive, has not yet taken any action. Donald Shopland, coordinator of the institute's smoking and tobacco control programme, said there may be legal restrictions on withdrawing funding from a current grant. Shopland added that Glantz, who is seeking renewal of his grant next year, probably would not receive further NCI funding for such work.

Kohn said Porter's committee took up the issue following an inquiry by the Washington Times of allegations by a group of taxpayers in Kentucky - a state where the tobacco industry is important economically - that NCI was using taxpayer money for political ends.

Porter investigated and reluctantly concluded that the group had a case. According to Kohn, Porter feared that opponents of the institute would use the issue to damage the agency. Porter does not represent a state with heavy tobacco interests, and has voted against tobacco industry subsidies, and in favour of a permanent ban on smoking on domestic airline flights. NCI officials also said the legislator had an excellent record for supporting NIH. Sally Lehrman development," explains John L. Zabriskie, who is currently chairman and chief executive officer of Upjohn, and who has been proposed as president and chief executive of the new company.

Indeed, executives at the new company believe the $\$ 1$ billion it will be spending on R\&D - a sum now considered as the minimum for world-class players - will bind the complementary strengths of both companies' current R\&D activities and further accelerate revenue growth in the new company's major therapeutic markets.

Pharmacia \& Upjohn has a strong pipeline of new products and indications. By 1998, the company expects to launch 18 new chemical entities and 12 new major indications and line extensions. The new company also has 24 products in earlyphase clinical testing, including promising cancer and central nervous system drugs, and has one of the world's strongest biotechnology capabilities with more than 1,000 scientists experienced in recombinant and monoclonal technologies. This should enhance the company's oncology and inflammation activities.

But while it says it will be a research intensive company, the management clearly believe that cost reductions - of more than $\mathbf{\$ 5 0 0}$ million a year - will make a substantial contribution to improved profitability. 